\title{
Hydrologic characteristics of vegetation types as affected by prescribed burning
}

\author{
JUSTIN W. HESTER, THOMAS L. THUROW, AND CHARLES A. TAYLOR, JR.
}

Authors are respectively, graduate research assistant and associate professor, Dept. of Rangeland Ecology and Management, Texas A\&M University, College Station, Tex. 77843 and superintendent, Texas Agricultural Experiment Station at Sonora, Tex. 76950.

Abstract

The objective of this study was to determine how rangeland hydrology of oak, juniper, bunchgrass and shortgrass vegetation types is altered by fire. The research was conducted at the Sonora Agricultural Experiment Station on the Edwards Plateau, Texas. Infiltration rate and interrill erosion were measured using a driptype rainfall simulator. Terminal infiltration rates of unburned areas were significantly greater on sites dominated by oak (Quercus virginiana Mill.) (200 mm hour ${ }^{-1}$ ) or juniper (Juniperus ashei Buchh.) (183 mm hour ${ }^{-1}$ ) than on sites dominated by bunchgrass (146 mm hour ${ }^{-1}$ ) or shortgrass $\left(105 \mathrm{~mm}\right.$ hour $\left.{ }^{-1}\right)$. Terminal infiltration rates on burned areas were significantly reduced on sites dominated by bunchgrass $\left(110 \mathrm{~mm}\right.$ hour $^{-1}$ ), shortgrass (76 mm hour $\left.{ }^{-1}\right)$, and on oak sites that were cut and burned $(129 \mathrm{~mm}$ hour $\left.{ }^{-1}\right)$. Soil organic matter content $(r=.61)$, total organic cover $(r=.59)$, and aggregate stability $(r=.53)$ were the variables most strongly correlated with infiltration rate. Measured soil structure properties were not altered by fire, therefore, differences in infiltration rate between unburned and burned treatments were attributable to variations in the amount of cover. The terminal infiltration rate of cut and burned juniper sites $\left(162 \mathrm{~mm} \mathrm{hour}^{-1}\right)$ was not changed significantly after the fire because the associated good soil structure properties allowed rapid infiltration even after cover was removed. Good soil structure properties were also present on the oak sites, but the infiltration rate significantly decreased as a result of the temporary hydrophobic nature of the soil on this site after burning. Prior to burning, interrill erosion was much lower under the tree sites (oak $=2 \mathrm{~kg} \mathrm{ha}^{-1}$; juniper $=34$ $\left.\mathrm{kg} \mathrm{ha}^{-1}\right)$ than on bunchgrass $\left(300 \mathrm{~kg} \mathrm{ha}^{-1}\right)$ or shortgrass $(1,299 \mathrm{~kg}$ $\mathrm{ha}^{-1}$ ) sites. After burning, interrill erosion significantly increased for all vegetation types (shortgrass $=5,766 \mathrm{~kg} \mathrm{ha}^{-1}$; bunchgrass = $4,463 \mathrm{~kg} \mathrm{ha}^{-1}$; oak $=4,500 \mathrm{~kg} \mathrm{ha}^{-1}$; juniper $\left.=1,926 \mathrm{~kg} \mathrm{ha}^{-1}\right)$. Total organic cover $(r=-.74)$ and bulk density at $0-30 \mathrm{~mm}(r=.46)$ were most strongly correlated with interrill erosion.

Key Words: fire, infiltration, erosion, Juniperus ashei, Quercus virginiana, bunchgrass, shortgrass

Increased dominance of shrubs and trees in what had previously been grasslands or savannas is a widely observed trend that appears to coincide with European settlement of rangelands (Archer 1994). One consequence of this change in relative com-

Authors thank R. Moen, A. Weichert, N. Garza, D. Carlson, B. Hays and D. Hays for their assistance with field work and data preparation.

Manuscript accepted 30 Mar. 1996.
Resumen

El objetivo de este estudio fue el de determinar como la hidrologia de diversos tipos de vegetación es alterada por el fuego. La investigación fue llevada a cabo en la Estación Experimental de Sonora, Texas, localizada sobre la Meseta Edwards en los Estados Unidos. La tasa de infiltración y erosión fueron medidas empleando un simulador de lluvias tipo goteo. Las tasas de infiltración terminal en áreas no quemadas fueron significativamente muyores en los sitios dominados por encino (Quercus virginiana) $(200 \mathrm{~mm} / \mathrm{h})$ o de Juniperus ashei) 183 $\mathrm{mm} / \mathrm{h}$ ), en comparacion con los sitios dominados por pastos amacollados $(146 \mathrm{~mm} / \mathrm{h})$ o con pastos cortos $(105 \mathrm{~mm} / \mathrm{h})$. Las tasas de infiltración terminal en las áreas quemadas fueron significativamente reducidas en los sitios dominados por pastos amacollados $(110 \mathrm{~mm} / \mathrm{h})$, pastos cortos $(76 \mathrm{~mm} / \mathrm{h})$, y en los sitios en donde los encinos fueron cortados y quemados $(129 \mathrm{~mm} / \mathrm{h})$. El contenido de materia orgánica del suelo $(r=.61)$, cubierta orgánica total $(r=$ $.59)$, y la estabilidad de los agregados del suelo $(r=.53)$ fueron las variables más fuertemente correlacionadas con la tasa de infiltración. Las propiedades de la estructura del suelo que fueron medidas no fueron alteradas por el fuego, por lo tanto, las diferencias en la tasa de infiltración entre las áreas quemadas y no quemadas, fueron atribuibles a variaciones en la cobertura. La tasa de infiltración terminal de los sitios de Juniperus cortado y quemado $(162 \mathrm{~mm} / \mathrm{h})$, no fue alterado significativamente después de la quema debido a que las propiedades asociadas de la estructura positiva del suelo permitieron una rápida infiltración aún después de que la cubierta vegetal fue removida. Una buena estructura del suelo también estuvo presente en el sitio con encino, más la tasa de infiltración disminuyo significativamente como resultado de la naturaleza temporal hidrofobica del suelo presente en este sitio después de la quema. Previa a la quema, la erosión fue mucho menor bajo los arboles (encino $=2$ $\mathrm{kg} / \mathrm{ha}$; Juniperus $=34 \mathrm{~kg} / \mathrm{ha}$ ) en comparación con las areas de pastos amacollados $(300 \mathrm{~kg} / \mathrm{ha})$ y de pastos cortos $(1,299 \mathrm{~kg} / \mathrm{ha})$. Después de la quema, la erosión se incremento significativamente en todos los tipos de vegetación (pastos cortos $=5,766 \mathrm{~kg} / \mathrm{ha}$; pastos amacollados $=4,463 \mathrm{~kg} / \mathrm{ha}$ encinos $=4,500 \mathrm{~kg} / \mathrm{ha}$; Juniperus $=$ $1,959 \mathrm{~kg} / \mathrm{ha})$. La cobertura orgánica total $(r=.74)$ y la densidad bruta a 0-30 mm $(r=.46)$ fueron las más fuertemente correlacionadas con la erosión.

position of vegetative cover is the amelioration of soil under the trees (Fisher 1990), resulting in an alteration of the hydrologic characteristics of the site (Thurow 1991). The accumulation of organic matter under trees and the moderation of soil microcli- 
mate (Kittredge 1948) favor earthworm and microbial activity, and the creation of water stable soil aggregates (Lal 1987). The cover provided by the canopy and litter intercept precipitation, thereby dissipating the kinetic energy of falling rain that could break the aggregate bonds. The enhanced soil structure that results from these factors improves infiltration. Consequently, infiltration rates are often observed to be highest under trees and shrubs, followed in decreasing order by bunchgrasses and sodgrasses (Box 1961, Blackburn 1975, Wood and Blackburn 1981, Knight et al. 1984, Thurow et al. 1986).

Water is one of the most valuable products of rangelands. There is increasing public demand to place greater emphasis on optimizing water yield from rangeland watersheds (Hibbert 1979) as the human population grows and water shortages worsen throughout many areas of the western U.S. (van der Leeden et al. 1990, Texas Water Development Board 1990). Many rangelands have the potential to yield more water if they are dominated by grasses instead of trees and shrubs (Blackburn 1983, Griffin and McCarl 1989). This increase is primarily attributable to reduced infiltration and evapotranspiration rates when the dominant vegetation on a site is changed from brush to grass (Hibbert 1979, 1983). Therefore, brush control for the sake of improving water yield is likely to become an increasingly important range management objective (Thurow and Taylor 1995). Brush control is also commonly used to achieve a variety of other management objectives such as to increase forage production or improve wildlife habitat. Fire is a natural component of Texas rangeland ecosystems and is a cost-effective tool for controlling brush (Scifres 1980). However, fire also increases the risk of erosion from storms that occur prior to vegetation regrowth (Tiedemann et al. 1978).

The objective of this research was to assess the influence of prescribed burning on the infiltration rate and interrill erosion of vegetation types dominated by either live oak (Quercus virginiana Mill.), Ashe juniper (Juniperus ashei Buchh.), bunchgrass or shortgrass. The impact of burning on hydrologic properties may vary considerably within and among plant communities due to the differential behavior of fire as influenced by variations in fuel characteristics associated with the plant composition (Tiedemann et al. 1978, Knight et al. 1983). Consumption of organic cover by fire decreases interception and exposes the soil to the direct impact of raindrops which can detach the soil and lead to decreased infiltration and increased interrill erosion. Burning also reduces litter and standing biomass that obstruct overland flow and associated sediment transport. Another danger associated with fire is that the soils may become hydrophobic. Heating distills organic substances which may condense on mineral soil particles (DeBano and Krammes 1966). This can create a water repellent coating that may restrict, or in some cases completely impede, water movement into soil (Meeuwig 1969), substantially increasing the runoff and erosion hazard on the site. Any mineral soil with an organic matter content of at least 1 to $2 \%$ is likely to become water repellent to some degree when heated (DeBano 1981). The amount of water repellency that occurs is a complex interaction that depends upon fire intensity, soil texture, soil moisture content, and the type and amount of organic matter. Shrubs with waxy leaf coats (e.g., $Q$. virginiana) or high essential oil content (e.g., J. ashei) seem to be particularly susceptible to water repellency (Debano 1981).

\section{Methods}

\section{Study Area}

The study was conducted at the Texas Agricultural Experiment Station located about $56 \mathrm{~km}$ south of Sonora, in Edwards County, Texas $\left(31^{\circ} \mathrm{N} ; 100^{\circ} \mathrm{W}\right)$. The rolling stony hill lopography that characterizes the station is typical of the Edwards Plateau. Soils of the study area were of the Tarrant silty clay series, which are members of the clayey-skeletal, montmorillonitic, thermic family of Lithic Haplustalls. The mean frost free period is 240 days, Precipitation is highly variable within and between years (median annual precipitation, $1919-1995=557 \mathrm{~mm}$; range $=156$ to 1,054 $\mathrm{mm})$. Most precipitation results from intense, short-duration thunderstorms.

The natural vegetation of the Edwards Plateau is a juniper-oak savannah (Kuchler 1964). The vegetation occurred as a mosaic of dense woody vigetation clusters dominated by either oak or juniper, with the tree cluster interspaces occupied by swards dominated by either bunchgrass or shortgrass. In recent decades the woody component has markedly increased throughout the region (Taylor and Smeins 1994). The composition of the dominant vegetation types on the study site was $18 \%$ live oak, $25 \%$ Ashe juniper and redberry juniper (Juniperus pinchotii (Sudw.)), $17 \%$ bunchgrass [dominated by sideoats grama (Bouteloua curtipendula (Michx.) Torr.), Texas wintergrass (Stipa leucotricha Trin. and Rupr.) and several Aristida spp.], and 40\% shortgrass [dominated by common curly mesquite (Hilaria belangeri (Steud.) Nash)]. The site had been, and continued to be, moderately stocked with sheep and goats (8.1 ha $\left.\mathrm{AU}^{\cdot 1}\right)$.

\section{Data Collection}

In February 1991 the woody vegetation on the study site was manually cut and removed (i.e., dragged into brush piles at the edge of the pastures) and in July 1991 a backfire was used to burn a portion of the site from which the brush had been removed. In the days immediately following the burn, a drip-type rainfall simulator (Blackburn et al. 1974) was used to determine infiltration rates and sediment yield from eight $0.5 \mathrm{~m}^{2}$ flexible-frame (roughly circular) runoff plots within each of the burned oak, juniper, bunchgrass and shortgrass sites and 8 similar plots within each unburned vegetation type. Thus, the oak and juniper burned and unburned sites had the trees cut and removed 5 months prior to the rainfall simulation tests; the unburned treatments of the tree plots still retained the litter accumulation associated with previous presence of the trees and the fire consumed the litter and herbaceous vegctation in the burned treatment. The microplots did not include the stumps of the trees. All microplots had approximately the same slope (4\%).

Data collected using microplots is not expected to reflect the actual runoff and sediment yield likely to occur from larger scales of resolution because as the size of the measurement unit increases a host of other water routing and sediment transport considerations will also influence the result. Rather, microplot data does provide a means with which to assess the hydrologic and erosion characteristics of the treatments relative to each other (Lal 1988). The plots were not pre-wetted and no rain occurred during the sample period. Simulated rainfall was applied at a rate of $203 \mathrm{~mm}$ hour $^{-1}$ for $50 \mathrm{~min}$. The simulated rate represents a storm return period of 150 years. This admittedly high rate was chosen to ensure runoff from all plots. This criterion was desirable so that the terminal infiltration rates could be compared between vegetation types and between burned and unburned treatments. 
Runoff was continuously collected and measured by weight at 5-minute intervals. Infiltration rates were determined for each 5minute interval by calculating the difference between applied rainfall and runoff collected on each plot. At the termination of the applied rainfall, a thoroughly mixed 1-liter subsample of the runoff was obtained. The subsample was filtered through a tared \#1 Whatman filter, dried at $105^{\circ} \mathrm{C}$ for 24 hours, weighed, and converted to sediment yield $\left(\mathrm{kg} \mathrm{ha}^{-1}\right)$ based on the area and total runoff from each plot and used to calculate sediment yield.

The type and percentage of foliar cover, litter, rock, and bare ground were determined by a top-down visual estimate for each runoff plot. This form of cover estimate determines what the raindrop will first strike as it falls to the ground. Total organic cover is the combination of foliar and litter cover; total cover includes rock cover and is the inverse of the amount of bare soil exposed to direct raindrop impact. Standing grass and forbs (live and dead) were clipped and litter was collected from each plot, dried at $60^{\circ} \mathrm{C}$, weighed and converted to $\mathrm{kg} \mathrm{ha}^{-1}$ to estimate aboveground biomass. A relief meter was used to measure the surface roughness of each plot (Kincaid and Williams 1966). Soil samples from the surface $80 \mathrm{~mm}$ were collected and analyzed for soil texture by the particle size distribution technique (Gee and Bauder 1986), soil organic carbon content using the WalkleyBlack method (Nelson and Sommers 1986) and soil aggregate stability by the wet-sieve procedure (Kemper and Rosenau 1986). Prior to application of simulated rainfall, a core $\left(107 \mathrm{~cm}^{-3}\right)$ of soil adjacent to each plot was collected at 0 to $30 \mathrm{~mm}$ and 50 to 80 $\mathrm{mm}$ depths to determine bulk density (Blake and Hartge 1986) and gravimetric soil moisture (Gardner 1986).

\section{Data Analysis}

Data were tested for normality using skewness and kurtosis analysis. The interrill erosion values were highly skewed warranting a $\log _{10}$ transformation prior to analysis. Differences between treatments were tested by analysis of variance, with the error term consisting of the nested variation of the randomized sites with the treatments (Dunn and Clark 1974). Treatment means were separated by Duncan's multiple-range test using a $5 \%$ confidence level. The degree of linear association of the variables most related to infiltration rate and sediment yield was determined using a Pearson's correlation matrix (r). Stepwise multiple regression analysis was used to identify the variables that most influence surface runoff and interrill sediment yield (SAS Institute 1988).

\section{Results}

\section{Infiltration Rate}

Terminal infiltration rates were approached on all plots (Fig. 1). Mean infiltration rates for each of the $5 \mathrm{~min}$. sample periods showed similar trends when correlated with other measured variables, but mean infiltration rates from measurements taken at 50 min. always showed the highest correlations. Therefore, in the following text, only mean infiltration rates at $50 \mathrm{~min}$. will be discussed.

Vegetation type had a strong influence on hydrology. The unburned oak and juniper vegetation types had significantly greater infiltration rates than the bunchgrass site, which in turn, had a significantly greater infiltration rate than the shortgrass site (Fig. 1, Table 1). Burning caused a decrease in the infiltration

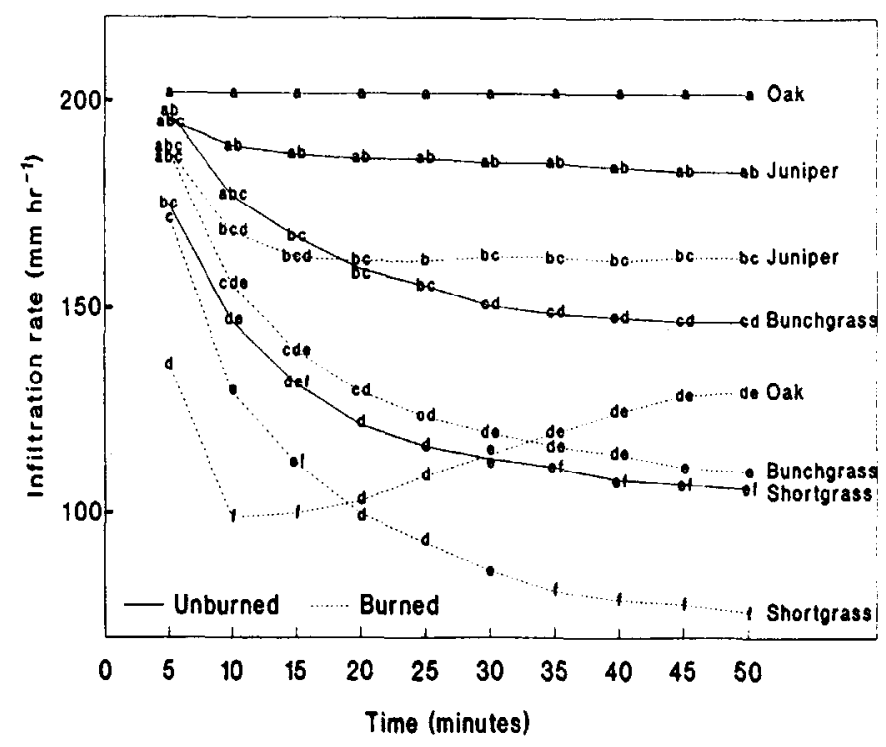

Fig. 1. Infiltration rates $\left(\mathrm{mm}\right.$ hour $\left.{ }^{-1}\right)$ for burned and unburned vegetation types during $50 \mathrm{~min}$. of simulated rainfall application, Edwards Plateau, Tex. Means for each 5 min. interval with the same letter for the same time period are not significantly different (ps.05).

rate of each vegetation type. The greatest change in infiltration rate occurred on the oak sites. Normally, infiltration rate steadily declines as the soil pore spaces fill with water, resulting in water entry into the soil reaching an equilibrium with the drainage characteristics of the soils at the site (i.e., the terminal infiltration rate). The burned oak sites did not follow this typical pattern because the fire created a temporary hydrophobic soil condition. Consequently, during the first $10 \mathrm{~min}$. of rainfall, water beadedup on the soil surface and quickly ran off the plot. The water repellent properties of the soil began to deteriorate as simulated rainfall continued, resulting in a gradual infiltration rate increase. The approximate terminal infiltration rate on the burned oak sites was $40 \%$ lower than on the unburned oak sites.

Soil organic matter content $(r=.62)$, total organic cover $(r=$ $.59)$, and aggregate stability $(r=.53)$ were the variables most strongly correlated with infiltration rate of the combined burned and unburned treatments data set. Soil organic matter content and aggregate stability were significantly greater on woody dominated sites than the grassy areas (Table 1). A stepwise regression analysis procedure was used to develop the following predictive model $\left(r^{2}=.61\right)$ for infiltration rate after $50 \mathrm{~min}$.:

Infiltration rate after $50 \mathrm{~min} .=-0.10+0.56$ (soil organic matter) +0.05 (total organic cover) +0.10 (aggregate stability)

A stepwise regression analysis of just the unburned sites yielded a slightly improved predictive model $\left(r^{2}=.64\right)$ :

Infiltration rate after $50 \mathrm{~min} .=3.76+0.82$ (soil organic matter) +0.06 (total organic cover)

A stepwise regression of the just the burned sites yielded a model with lower predictive capacity $\left(r^{2}=.40\right)$ :

Infiltration rate after $50 \mathrm{~min} .=0.03+0.45$ (soil organic matter) +0.11 (aggregate stability) 
Burning did not alter the characteristics of soil structure (i.e., aggregate stability, bulk density, or soil organic matter) but it did remove the organic cover (Table 1). The lower coefficient of determination for the burned site model is attributable to the highly correlated total organic cover variable dropping out as a predictive element because it had been eliminated by the fire and thus was no longer a differentiating factor between treatments. Infiltration rates were reduced on the burned sites because there was less organic cover to dissipate the energy of rain and less biomass to obstruct overland flow. Burning also made the soil of the oak sites hydrophobic, thus even though the soil of the oak sites had good structure it also had a relatively low infiltration rate.

The combination of these factors contributed to the result that infiltration rate had a poorer correlation with variables that reflect soil structure on the burned sites (soil organic matter $r=.58$, aggregate stability $r=.57$, bulk density at $0-30 \mathrm{~mm} r=-.40$ ) than on the unburned sites (soil organic matter $r=.77$, aggregate stability $\mathrm{r}=.62$, bulk density at $0-30 \mathrm{~mm} \mathrm{r}=-.61$ ).

\section{Interrill Erosion}

Sediment yield was lowest on the oak and juniper sites, followed in increasing order by the bunchgrass and shortgrass sites (Table 1, Fig. 2). This pattern was most strongly correlated with the total organic cover $(r=-.74)$ and bulk density at $0-30 \mathrm{~mm}(\mathrm{r}$ $=.46$ ) for the combined burned and unburned treatments data set. A stepwise regression analysis procedure yielded the following predictive model for estimating sediment yield $\left(r^{2}=.65\right)$ :

$\log _{10}$ sediment yield after $50 \mathrm{~min} .=0.18-0.03$ (total organic cover) +3.62 (bulk density at $0-30 \mathrm{~mm}$ ).

A stepwise regression analysis of just the unburned sites yielded a slightly improved predictive model $\left(r^{2}=.74\right)$ :

$\log _{10}$ sediment yield after $50 \mathrm{~min} .=0.32+5.00$ (bulk density at $0-30 \mathrm{~mm}$ ) -0.49 (soil organic matter) +0.01 (total biomass).

A predictive equation for sediment yield on the burned sites could not be constructed because no variable met the 0.15 significance level for entry into the model. After the fire, no organic cover remained to dissipate the energy of falling raindrops and no biomass remained to obstruct runoff that would transport soil. This, and the increased runoff volume associated with lowered infiltration rates, explains the increase of sediment yield on the burned sites (Fig. 2). Soil structure factors had much poorer correlation with sediment yield on the burned sites (soil organic mat-

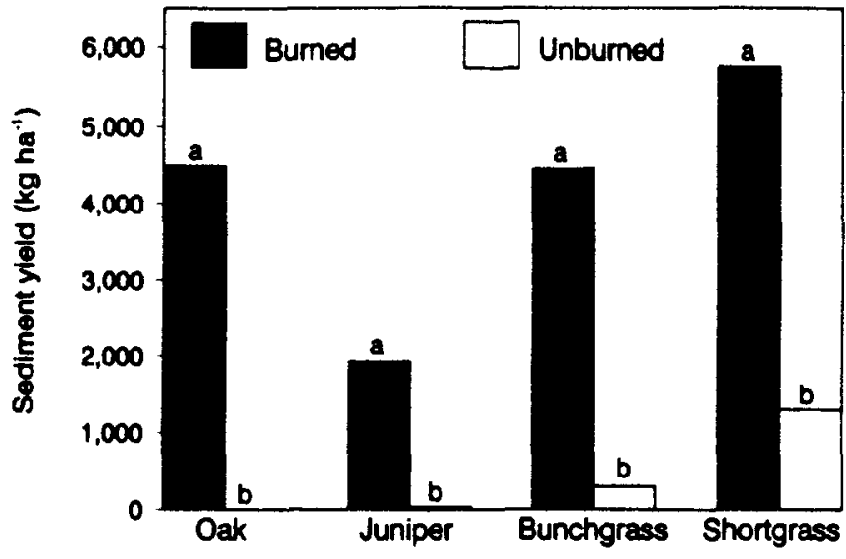

Fig. 2. Sediment yield $\left(\mathrm{kg} \mathrm{ha}^{-1}\right)$ for burned and unburned vegetation types, Edwards Plateau, Tix. Means within the same vegetation type with the same letter are not significantly different $(p \leq .05)$.

ter $\mathrm{r}=-.22$, aggregate stability $\mathrm{r}=-.31$, bulk density at $0-30 \mathrm{~mm}$ $r=-.19$ ) than on the unburned sites (soil organic matter $r=-.71$, aggregate stability $r=-.48$, bulk density at $0-30 \mathrm{~mm} \mathrm{r}=.77$ ).

\section{Discussion}

Litter accumulation under both oak $\left(41,889 \mathrm{~kg} \mathrm{ha}^{1}\right)$ and juniper $\left(54,522 \mathrm{~kg} \mathrm{ha}^{-1}\right)$ was significantly greater than on either bunchgrass (1496 kg ha-1) and shortgrass (482 $\mathrm{kg} \mathrm{ha}^{-1}$ ) sites. Total above-ground biomass was not as well correlated with infiltration rate $(r=.47)$, as it sometimes is (Warren et al. 1986), because the litter accumulation on the oak and juniper sites was disproportionately greater than the associated increase in infiltration rate when compared with the grass-dominated sites. Another reason was that the more compact juniper litter weighed more than the oak litter, but the soil structure and hence the infiltration rate of the oak site tended to be slightly higher.

Litter helps to dissipate the energy of raindrops and overland flow, thereby reducing the potential detachment and transport of soil. Litter also helps to moderate the soil microclimate and provides food for microorganisms. These factors favor increased biotic activity that creates soil macropores and aids aggregation of soil particles through mechanical binding by fungal hyphae. Organic matter decay and microbial synthesis yield adhesive byproducts that help bind soil particles together. These bound particles are then cemented together by resistant humus components which form chemical bonds (Brady 1990). These types of

Table 1. Site variables most strongly correlated with infiltration rate and sediment yield after $\mathbf{5 0}$ min. simulated rainfall, Edwards Plateau, Tex. Values within a row with the same letter indicate no significant difference $(p \leq .05)$.

\begin{tabular}{|c|c|c|c|c|c|c|c|c|}
\hline & \multicolumn{2}{|c|}{ Oak } & \multicolumn{2}{|c|}{ Juniper } & \multicolumn{2}{|c|}{ Bunchgrass } & \multicolumn{2}{|c|}{ Shortgrass } \\
\hline & Burned & Unburned & Bumed & Unburned & Burned & Unburmed & Burned & Unburned \\
\hline Infiltration rate (mm hour ${ }^{-1}$ ) & 129 de & $202 a$ & $162 \mathrm{bc}$ & $183 \mathrm{ab}$ & $110 \mathrm{e}$ & $146 \mathrm{~cd}$ & $76 f$ & $105 \mathrm{ef}$ \\
\hline Sediment yield $\left(\mathrm{kg} \mathrm{ha}^{-1}\right)$ & $4500 \mathrm{a}$ & $2 b$ & $1926 \mathrm{~b}$ & $34 b$ & $4463 a$ & $300 \mathrm{~b}$ & $5766 a$ & $1299 \mathrm{~b}$ \\
\hline Total organic cover (\%) & $0.0 \mathrm{~d}$ & $100.0 \mathrm{a}$ & $0.0 \mathrm{~d}$ & $100.0 \mathrm{a}$ & $0.0 \mathrm{~d}$ & $67.9 \mathrm{~b}$ & $0.0 \mathrm{~d}$ & $43.5 c$ \\
\hline Soil organic matter $(\%)$ & $12.3 \mathrm{a}$ & $11.9 \mathrm{ab}$ & $10.6 b$ & $10.4 b$ & $5.7 \mathrm{c}$ & $6.9 \mathrm{c}$ & $5.3 \mathrm{c}$ & $5.9 \mathrm{~cd}$ \\
\hline Aggregate stability (\%) & $81.2 \mathrm{a}$ & $84.5 \mathrm{a}$ & $86.5 a$ & $81.5 \mathrm{a}$ & $66.0 \mathrm{~b}$ & $67.0 \mathrm{~b}$ & $62.3 \mathrm{~b}$ & $67.1 \mathrm{~b}$ \\
\hline Bulk density 0-30 $\mathrm{mm}\left(\mathrm{Mg} \mathrm{mm}^{-3}\right)$ & $0.64 b$ & $0.51 \mathrm{c}$ & $0.70 \mathrm{~b}$ & $0.76 \mathrm{~b}$ & $0.97 \mathrm{a}$ & $1.00 \mathrm{a}$ & $0.95 \mathrm{a}$ & $0.97 \mathrm{a}$ \\
\hline Bulk density $50-80 \mathrm{~mm}\left(\mathrm{Mg} \mathrm{mm}^{-3}\right)$ & $0.88 \mathrm{ab}$ & $0.66 \mathrm{c}$ & $0.81 \mathrm{~b}$ & $0.97 \mathrm{a}$ & $0.99 \mathrm{a}$ & $0.96 \mathbf{a}$ & $1.01 \mathrm{a}$ & $0.98 \mathrm{a}$ \\
\hline
\end{tabular}


bonds help to maintain the structural integrity of the pores through which water must flow when entering the soil (Boyle et al. 1989) and thereby influence infiltration rate. Therefore, the greater organic matter cover and the improved soil structure under trees result in greater infiltration and less interrill erosion. Bunchgrass sites have a higher percentage of these favorable traits than shortgrass sites, therefore bunchgrass sites have greater infiltration rates and less sediment yield than shortgrass sites (Thurow el al. 1988).

Soil structure was more strongly correlated with infiltration and sediment yield on the unburned sites than on the burned sites, even though the measured soil structure for a given vegetation type was not different between the burned and unburned sites. Several factors account for this difference. The hydrophobic characteristics of the burned oak site reduced infiltration rate even though the soil structure remained the same. Also, after the simulated rainfall application was finished, a thin surface crust was apparent on portions of the burned plots. This indicates that soil structural characteristics within the first several $\mathrm{mm}$ of the surface soil had been disrupted by raindrops that did not have their kinetic energy dissipated by first striking foliar or litter cover. Since soil structural characteristics were analyzed from a composite sample of the top $80 \mathrm{~mm}$, the analyses were not sensitive enough to detect this breakdown in soil structure within the top several $\mathrm{mm}$. As the soil pores at the surface were clogged with ash and disaggregated soil particles, the infiltration rate would be expected to drop. The increased runoff would have greater ability to detach and transport soil, thus increasing sediment yield. Therefore, the hydrophobic conditions and soil crusting weakened the relationship of infiltration rate and sediment yield with the composite soil structure characteristics measured in the top 80 $\mathrm{mm}$.

The distribution of 4 vegetation types of this study occur as a patchwork mosaic across the rangeland. This distribution is not related to inherent differences in the surface soil; there was no difference in the sand $(19 \%)$, silt $(40 \%)$ or clay $(41 \%)$ content between the different vegetation types. Consequently, textural changes between vegetation types, such as in the coppice dune systems of the U.S. Great Basin (Blackburn 1975), do not occur. Hence, soil texture is poorly related to infiltration rate differences found on the study site $\left(r^{2}<.1\right)$.

Fire consumes the organic cover, thereby increasing the exposure of the soil to the erosive forces of rain and runoff (Meeuwig 1969, Roundy et al. 1978, Cheruiyot et al. 1986). Burning of the oak litter created a hydrophobic soil condition. This phenomenon is common when fire burns waxy coated leaves, resulting in some of the wax reforming to create a water resistant coating on the soil particles (DeBano 1981). The oak litter may also have produced an increase in fire temperature that led to excessive drying of a fine layer of soil, making it difficult to re-wet (DeBano et al. 1967).

\section{Management Implications}

The combination of heavy grazing, droughts, and a reduction in fire frequency have aided the increase of oak and juniper on the Edwards Plateau (Taylor and Smeins, 1994). This region is a very important source of water for Texas, especially since the current water supply does not meet the projected demand (Texas Water Development Board 1990). Brush dominated sites lose substantially more water to evapotranspiration and produce less forage than grasslands (Hibbert 1983). Enhancing water and forage yield provides an economic impetus for brush control (Rowan and Conner 1994). Fire is an effective, cost-efficient tool for managing brush (Scifres 1980). However, when fire consumes the organic cover it exposes the soil to direct raindrop impact which leads to a reduction in infiltration and an increase in interrill erosion. The susceptibility to runoff and interrill erosion can be further exacerbated if fire creates hydrophobic conditions (DeBano 1981).

The results of this study provide a relative index of the increased risk of runoff and interrill erosion that is present immediately after a fire. Even though fire reduced the infiltration rate on the oak and juniper vegetation types, these sites still had a greater infiltration rate than unburned grassland. This was because of the ameliorative effect that trees have on soil structure which is maintained after the organic cover has been bumed. Soil structure was not as well developed in the bunchgrass and shortgrass vegetation types as on the wooded sites. Therefore, the grass sites were more susceptible to runoff and interrill sediment yield, especially after the protective cover was consumed by fire.

The gentle slope (4\%), gently undulating surface topography, and the extent ( $40 \%$ canopy cover) and pattern of the woody vegetation mosaic is not conducive to enabling runoff to bypass oak and juniper mottes via concentrated flow paths. Therefore, when water begins to run off of a low infiltration site it does not flow very far before it encounters a different vegetation type with a greater infiltration rate. The sites with a greater infiltration rate can often accommodate the overland flow in addition to the incident rainfall. In this manner, overland flow redistributes the water within the pasture (Cornet et al. 1992) and only about $2 \%$ of annual precipitation actually leaves a pasture as runoff before or after the trees are cut and removed (Thurow and Taylor 1995). These data imply that cut and burned tree groves, which retain a high infiltration potential because the associated good soil structure remains even after the trees are gone, do not pose as much of a threat to runoff and interrill erosion as would the associated burned grass interspaces. Therefore, to minimize runoff and erosion risk, tree groves should be burned as spot fires. An alternative would be to limit the use of prescribed fires that burn the entire pasture to seasons of the year when the risk of high intensity storms is low. In the case of west Texas, the low intensity frontal storms which characterize winter precipitation events pose less runoff and erosion threat to exposed soil than the high-intensity convective storms which characterize summer precipitation events.

\section{Literature Cited}

Archer, S. 1994. Woody plant encroachment into southwestern grasslands and savannas: rates, patterns and proximate causes. p. 36-68 In: M. Vavra, W. Laycock and R. Pieper (eds.) Ecological implications of livestock herbivory in the West. Society for Range Management, Denver, Colo.

Blackburn, W.H. 1975. Factors influencing infiltration and sediment production of semiarid rangelands in Nevada. Water Resour. Res. 11:929-937.

Blackburn, W.H. 1983. Influence of brush control on hydrologic characteristics of range watersheds. Proceedings, Brush Management Symposium, Society for Range Management, pp. 73-88.

Blackburn, W.H., R.O. Meeuwig, and C.M. Skau. 1974. A mobile infiltrometer for use on rangeland, J. Range Manage. 27: 322-323. 
Blake, R.G. and K.H. Hartge. 1986. Bulk density, p. 363-376. In: A. Klute (ed.), Methods of soil analysis, Part 1. Physical and mineralogical methods. Amer. Soc. Agron., Agron. Ser. No. 9, Madison, Wis.

Box, T.W. 1961. Relationships between plants and soils of 4 range plant communities within south Texas. Ecol. 42:794-810.

Boyle, M., W.T. Frankenburger, Jr., and L.H. Stolzy. 1989. The influence of organic matter on soil aggregation and water infiltration. $\mathbf{J}$. Prod. Agr. 2:290-299.

Brady, N.C. 1990. The nature and properties of soils. 8th ed. Macmillan, New York, N.Y.

Cheruiyot, S.K., W.H. Blackburn, and R.D. Child. 1986. Infiltration rates and sediment production of a Kenya bushed grassland as influenced by prescribed burning. Trop. Agric. 63:177-180.

Cornet, A.F., C. Montana, J.P. Delhoume and J. Lopez-Portillo. 1992. Water flows and the dynamics of desert vegetation stripes. $p$ 327-345. In: A.J. Hansen and F. di Castri (eds.). Landscape Boundaries: Consequences for Biotic Diversity and Ecological Flows. Springer-Verlag, New York, N.Y.

DeBano, L.F. 1981. Water repellent soils:a state-of-the-art. USDA Pacific Southwest Forest and Range Exp. Sta. Gen. Tech. Rep. PSW46.

DeBano, L.F. and J.S. Krammes. 1966. Water repellent soils and their relation to wildfire temperatures. Int. Assoc. Sci. Hydrol. Bull., XI Annee 2:14-19.

Debano, L.F., J.F. Osborn, J.S. Krammes, and J. Letey, Jr. 1967. Soil wetability and wetting agents...our current knowledge of the problem. USDA Forest Serv. Res. Paper. Pacific Southwest Forest and Range Exp. Stn.. Berkeley, Calif. PSW-43.

Dunn, O.J. and V.A. Clark. 1974. Applied statistics: Analysis of variances and regression. John Wiley and Sons, Inc., New York, N.Y.

Fisher, R.F. 1990. Amelioration of soils by trees. p. 290-300. In: S.P. Gessel, D.S. Lacate, G.F. Weetman, and R.F. Powers (eds.), Sustained productivity of forest soils. Proceedings of the 7th North American Forest Soils Conference. Univ. British Columbia, Vancouver.

Gardner, W.H. 1986. Water content, p. 493-544. In: A. Klute (ed.), Methods of soil analysis, Part 1. Physical and mineralogical methods. Amer. Soc. Agron., Agron. Ser. No. 9, Madison, Wis.

Gee, G.W. and J.W. Bauder. 1986. Particle-size analysis, p. 399-404. In: A. Klute (ed.), Methods of soil analysis, Part 1. Physical and mineralogical methods. Amer. Soc. Agron., Agron. Ser. No. 9, Madison, Wis.

Griffin, R.C. and B.A. McCarl. 1989. Brushland management for increased water yield in Texas. Water Resour. Bull. 25:175-186.

Hibbert, A.R. 1979. Managing vegetation to increase flow in the Colorado River Basin. USDA, Forest Service, General Tech. Report RM-66.

Hibbert, A.R. 1983. Water yield improvement potential by vegetation management on western rangelands. Water Resour. Bull. 19:375-381.

Kemper, W.D. and R.C. Rosenau. 1986. Aggregate stability and size distribution, p. 425-442. In: A. Klute (ed.), Methods of soil analysis, Part 1. Physical and mineralogical methods. Amer. Soc. Agron., Agron. Ser. No. 9, Madison, Wis.

Kincaid, D.R. and G. Williams. 1966. Rainfall effects on soil surface characteristics following range improvements. J. Range Manage. $19: 346-351$

Kittredge, J. 1948. Forest influences. McGraw-Hill Book Co. Inc., New York, N.Y.

Knight, R.W., W.H. Blackburn, and L.B. Merrill. 1984. Characteristics of oak mottes, Edwards Plateau, Texas. J. Range Manage. 37:534-537.

Knight, R.W., W.H. Blackburn, and C.J. Scifres. 1983. Infiltration rates and sediment production following herbicide/fire brush treatments. J. Range Manage. 36:154-157.

Kuchler, A.W. 1964. Potential natural vegetation of the conterminous United States. Am. Geog. Soc. Spec. Pub. No. 36.

Lal, R. 1987. Tropical ecology and physical edaphology. John Wiley and Sons, New York, N.Y.

Lal, R. 1988. Soil erosion research methods. Soil and Water Conservation Society, Ankeny, lowa.
Meeuwig, R.O. 1969. Infiltration and soil erosion on Coolwater Ridge, Idaho. USDA Forest Serv. Res. Note INT-103. Intermountain Forest and Range Exp. Stn., Ogden, Utah.

Nelson, D.W. and L.E. Sommers. 1986. Total carbon, organic carbon, and organic matter, p. 539-577. In: A. Klute (ed.), Methods of soil analysis, Part 2. Chemical and microbiological properties. Amer. Soc. Agron., Agron. Ser. No. 9, Madison, Wis.

Roundy, B.A., W.H. Blackburn, and R.E. Eckert, Jr. 1978. Influence of prescribed burning on infiltration and sediment production in the pinyon-juniper woodland, Nevada. J. Range Manage. 31:250-253.

Rowan, R.C. and J.R. Conner. 1994. Economic considerations in the control of ashe juniper. p. 69-78. In: C.A. Taylor (ed.), Juniper Symp. Texas Agricultural Experiment Station. Sonora, Tex. Tech. Rep. 94-2.

SAS Institute. 1988. SAS/STAT user's guide, release 6.03 edition. SAS Institute Inc., Cary, NC.

Scifres, C.J. 1980. Brush management. Texas A\&M Univ. Press. College Station, Tex.

Taylor, C.A., Jr, and F.E. Smeins. 1994. A history of land use of the Edwards Plateau and its effect on the native vegetation. p. 1-8. In: C.A. Taylor Jr. (ed.), Juniper Symp. Texas Agricultural Experiment Station. Sonora, TX. 'Tech. Rep. 94-2.

Texas Water Development Board. 1990. Water for Texas today and tomorrow. Document No. GP-5-1.

Thurow, T.L. 1991. Hydrology and erosion. p. 141-159. In: R.K. Heitschmidt and J.W. Stuth (eds.), Grazing management: An ecological perspective. Timber Press, Portland, Ore.

Thurow, T.L. and C.A. Taylor, Jr. 1995. Juniper effects on the water yield of central Texas rangeland. p. 657-665. In: R. Jensen (ed.), Proc. of the 24th water for Texas conference. Texas Water Resources Institute, College Station, Tex.

Thurow, T.L., W.H. Blackburn, and C.A. Taylor, Jr. 1986. Hydrologic characteristics of vegetation types as affected by livestock grazing systems, Edwards Plateau, Texas. J. Range Mange. 39:505-509.

Thurow, T.L., W.H. Blackburn, and C.A. Taylor, Jr. 1988. Infiltration and interrill erosion responses to selected livestock grazing strategies, Edwards Plateau, Texas. J. Range Manage. 41:296-302.

Tiedemann, A.R., C.E. Conrad, J.H. Dieterich, J.W. Hornbeck, W.F. Megahan, L.A. Vierech, and D.D. Wade. 1978. Effects of fire on water: a state of knowledge in review. In: USDA For. Ser. Gen. Tech. Rep. WO-10.

van der Leeden, F., F.L. Troise, and D.K. Todd. 1990. The water encyclopedia. Lewis Publishers, Chelsea, Mich.

Warren, S.D., W.H. Blackburn, and C.A. Taylor, Jr. 1986. Effects of season and stage of rotation cycle on hydrologic condition of rangeland under intensive rotation grazing. J. Range Manage. 39:486-491.

Wood, M.K. and W.H. Blackburn. 1981. Grazing systems: Their influence on infiltration rates in the rolling plains of Texas. J. Range Mange. 34:331-335. 